\title{
Structural Lesions of the Brain in Young Schizophrenics
}

\author{
P. AVERBACK
}

SUMMARY: Swollen, degenerate and fragmented neurons of the septal nuclei and the nucleus ansae peduncularis are commonly found in chronic neurological diseases such as Alzheimer's or Huntington's disease, and are rarely found in neurologically normal control patients without mental symptoms. These pathological lipid and pigment laden neurons appear to be a common feature of schizophrenia and have been consistently found in a series of unselected young (mean age 38) schizophrenics.

RESUME: Dans les maladies neurologiques chroniques telle la chorée de Huntington et la maladie d'Alzheimer, il est fréquent de trouver dans les noyaux septaux et de l'anse pédonculaire, des neurones gonflés, dégénérés et fragmentés. Ces formations se retrouvent rarement chez les témoins neurologiquement normaux sans symptomes mentaux. De tels neurones pathologiquement remplis de lipides et de pigments semblent être une condition presque constante dans la schizophrénie, ayant été trouvés régulièrement dans une série non présélectionnée de jeunes schizophrènes (âge moyen 38).

From the Department of Pathology, University of Cambridge.

Reprint requests to P. Averback, M.D., Department of Pathology, University of Cambridge, Tennis Court Road, Cambridge, U.K. CB2 1QP.

\section{INTRODUCTION}

A distinctive cellular lesion has been recently found in limbic neurons in patients with a variety of chronic neurological,diseases and schizophrenia (Averback, 1980). Massive swollen neurons filled with lipid vacuolar and pigment material are commonly seen in the nucleus ansae penduncularis (N.A.P.) and the septal nuclei, and are rarely found in neurologically normal patients without mental symptoms. In order to explore further the relevance of this newly recognized lesion to the problem of schizophrenia, a series of 13 postmortem schizophrenic brains was collected, with particular reference to young subjects with no substantial clinical or pathological evidence of dementia. This report details the pathological findings in this group of patients and age and sex matched controls.

\section{Materials and Methods}

Patients and controls are summarized in the table. This study was retrospective and precise clinical correlation was not attempted. Diagnostic criteria for the schizophrenic group were impossible to validate. Each patient had been hospitalized at least once for psychiatric illness labelled as schizophrenia. Each brain (except patient 11, with an embolic infarction in the territory of the $\mathrm{L}$ middle cerebral artery) was considered normal by conventional criteria by at least two observers. Further details are presented in the table. Normal controls consisted of consecutive autopsy material available from patients without neurological disease or mental symptoms. They had normal brains with no gross lesions.

Tissue blocks containing the nucleus ansae penduncularis (N.A.P.) and the nuclei of the septum pellicidum (both regions as defined by Mettler (1948)), were embedded in paraffin, sectioned. at multiple levels and stained with hematoxylin and eosin, and in some instances by other histochemical procedures (Periodic acid Schiff (P.A.S.), Sudan black, silver impregnation, Nissl). Quantitative aspects of this problem were not addressed; the criterion for a positive lesion was qualitatively significant cellular degeneration in an identifiable paracentral region of the nucleus (peripheral samples were considered inadequate). The septal nuclei as defined by Mettler were grouped together in this study. Control cytology of the septal region for older patients was not included in the author's cited references. Fresh and formalin fixed samples were also embedded in Spurr resin and thin sectioned for electron microscopic study (fixed in $1 \%$ glutaraldehyde, stained with uranyl acetate and lead citrate, and examined in a Philips 300 electron microscope). Selected formalin fixed blocks were used for frozen section study, including special stains (Oil Red O, Baker's, P.A.S., Nile blue sulfate) and examined for autofluorescence.

\section{RESULTS}

The normal controls in no instances showed the degree of lipid distention which was found in 13 of 13 from the schizophrenic group. The swollen neurons showed the typical morphology described in detail elsewhere (Averback, 1980a): massive vacuolar distortion of perikaryon resulting in bizarre cellular shapes, crowding of nuclei to cell periphery, fragmentation of occasional cells, and abundant pigment in some cells (Figures 1-3). The vacuoles did not stain by any method in paraffin sections as the lipid was extracted by solvent contact during processing, but frozen sections revealed positive staining material (positive with Oil Red $\mathrm{O}$, 


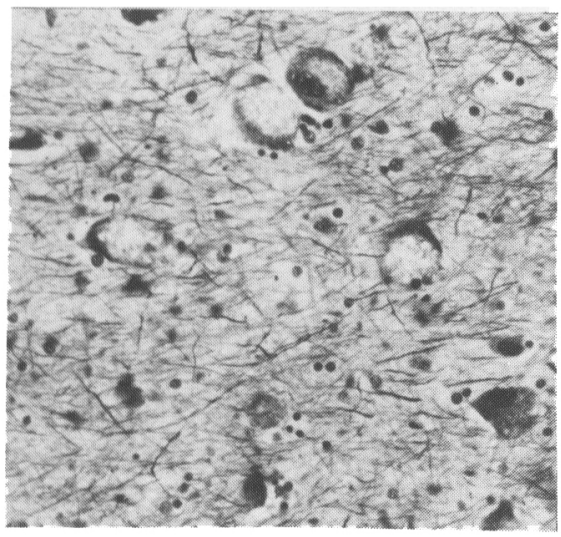

Figure 1 - Swollen neurons of the nucleus ansae peduncularis in schizophrenia. Gros-Bielschowsky silver impregnation, $\mathrm{x} 450$.

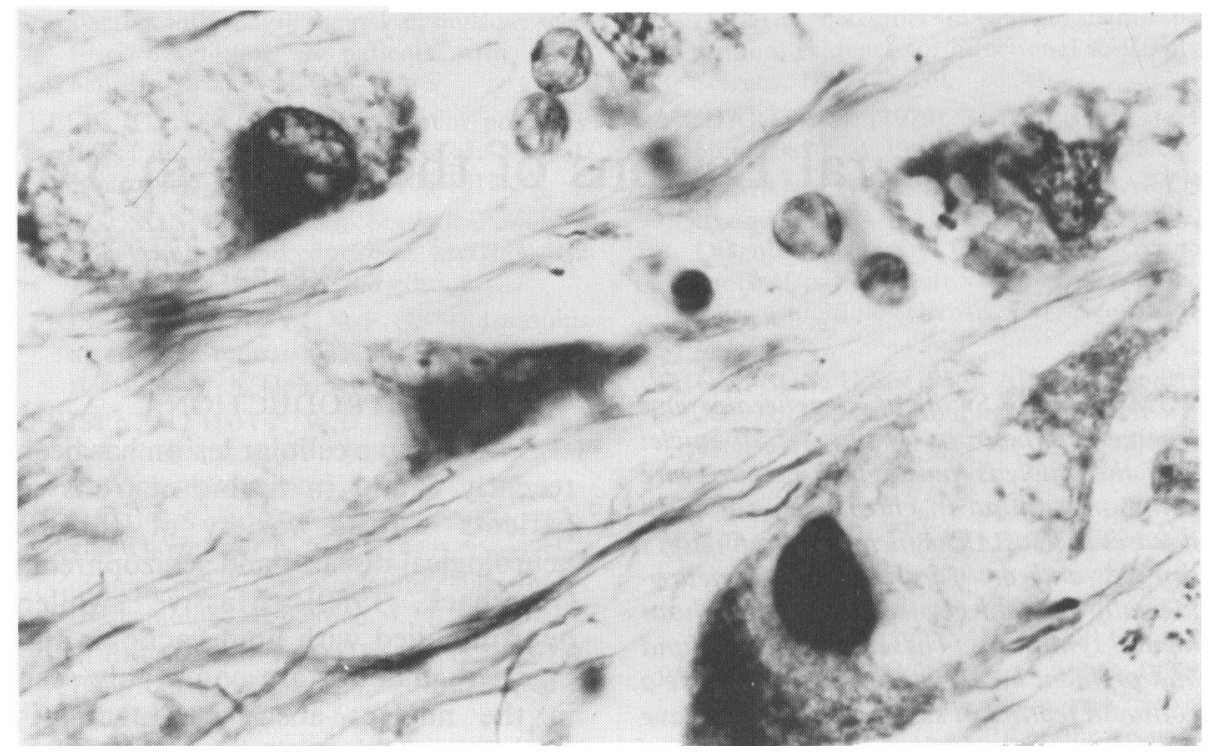

Figure 2 - Higher magnification of swollen N.A.P. neurons in schizophrenia. GrosBielschowsky, x 1,800.

Neurologically normal patients without mental symptoms under the age of 50 have thus far not shown appreciable evidence of obvious cellular degeneration. The problem of normal and pathological, in this as in some other types of presumed neuronal fallout, will need carefully determined cell count data. On the other hand, evidence of enormous bloating and neuronal death in the central nervous system, as shown in these neurons (Averback, 1980), should be regarded as normal with some degree of reservation.

These lesions have been found in patients with Alzheimer's disease, Huntington's disease, Parkinson's disease, and other neurological conditions. The neuroanatomical topography and detailed ultrastructure of the cells are distinctive amongst the known degenerative changes of neurons. The distention is so reminiscent of storage disease pathology that lysosomal enzyme abnormality, however unlikely, bears consideration. Granulo-vacuolar degeneration (g.v.d.) of the hippocampus, an "aging" change, shows superficial similarities: g.v.d. is characterized by vacuoles and dense material (the vacuoles are clear, the pigment is different and neurofibrillary changes are also seen (Hirano

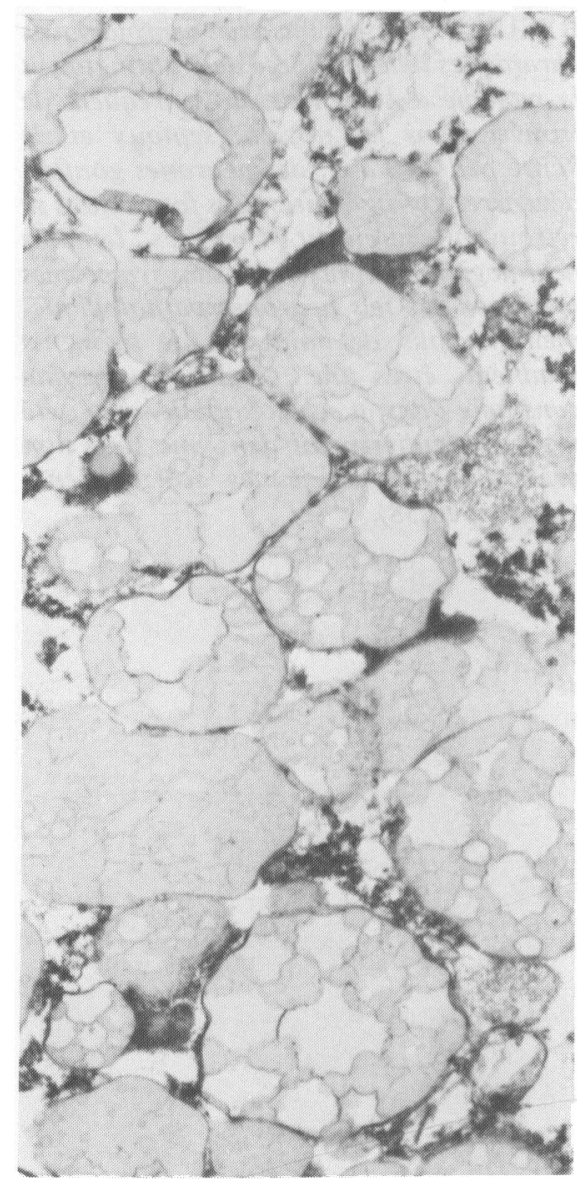

Figure 3 - Masses of perikaryal lipid droplets in swollen N.A.P. neuron. E.M., uranyl acetate and lead citrate, x 24,000. 
TABLE 1

Schizophrenics and Controls

\begin{tabular}{|c|c|c|c|c|c|c|c|c|c|}
\hline $\begin{array}{l}\text { Patient } \\
\text { number }\end{array}$ & Sex & $\begin{array}{l}\text { Age at } \\
\text { onset }\end{array}$ & $\begin{array}{l}\text { Age at } \\
\text { death }\end{array}$ & Diagnosis & Cause of death & $\begin{array}{l}\text { Neuropathological } \\
\text { findings }\end{array}$ & $\begin{array}{l}\text { NAP } \\
\text { cells }\end{array}$ & $\begin{array}{l}\text { Septal } \\
\text { cells }\end{array}$ & Other \\
\hline 1 & F & 33 & 43 & $\mathrm{~S}^{*}$ & $\begin{array}{l}\text { postoperative complications } \\
\text { after uterine prolapse }\end{array}$ & N.B. ${ }^{* * *}$ & + & + & leucotomy patient \\
\hline 2 & $\mathrm{~F}$ & uncertain & 48 & $\mathrm{~S}$ & $\begin{array}{l}\text { anaplastic carcinoma of } \\
\text { maxillary antrum }\end{array}$ & N.B. & + & + & \\
\hline 3 & $\mathbf{M}$ & 24 & 29 & $\mathrm{~S}$ & suicide by hanging & N.B. & + & + & also alcoholic \\
\hline 4 & $\mathbf{F}$ & uncertain & 44 & $\mathrm{~S}$ & pyelonephritis & N.B. & & & \\
\hline 5 & F & 21 & 39 & S & asphyxia & N.B. & + & $\begin{array}{l}\text { tissue not } \\
\text { available }\end{array}$ & $\begin{array}{l}\text { strong family history of } \\
\text { psychiatric disorders }\end{array}$ \\
\hline 6 & $\mathrm{~F}$ & 30 & 50 & S & myocardial infarction & N.B. & + & + & diabetes mellitus \\
\hline 7 & $\mathbf{M}$ & 20 & 37 & S & perforated ulcer & N.B. & + & $\begin{array}{l}\text { tissue not } \\
\text { available }\end{array}$ & \\
\hline 8 & $\mathbf{M}$ & 37 & 37 & S & acute suppurative bronchiolitis & N.B. & + & - & \\
\hline 9 & $\mathbf{M}$ & 29 & 38 & S & aspiration & N.B. & + & + & subnormal I.Q. \\
\hline 10 & $\mathbf{F}$ & 22 & 46 & $S$ & uncertain & N.B. & + & + & \\
\hline .11 & $\mathbf{F}$ & 34 & 47 & S & cerebral embolism & $\begin{array}{l}\text { occlusion of } \mathbf{L} \text {. } \\
\text { internal carotid } \\
\text { A. and infarction } \\
\text { in distribution of } \\
\text { L. middle cerebral A. }\end{array}$ & + & + & \\
\hline 12 & $\mathrm{~F}$ & 24 & 30 & S & status epilepticus & & + & + & $\begin{array}{l}\text { no previous history of } \\
\text { epilepsy before death }\end{array}$ \\
\hline 13 & $\mathbf{M}$ & 36 & 36 & $\mathbf{S}$ & insulin overdosage & N.B. & + & + & \\
\hline 1 & $\mathbf{M}$ & & 58 & N.C.** & trauma & & - & - & \\
\hline 2 & $\mathrm{~F}$ & & 22 & N.C. & D.1.C. & & - & - & \\
\hline 3 & $F$ & & 22 & N.C. & trauma & & - & - & \\
\hline 4 & $\mathbf{M}$ & & 55 & N.C. & trauma & & - & - & \\
\hline 5 & $\mathbf{M}$ & & 36 & N.C. & trauma & & - & - & \\
\hline 6 & F & & 62 & N.C. & amyloidosis & & - & - & \\
\hline 7 & $\mathbf{M}$ & & 30 & N.C. & trauma & & - & - & \\
\hline 8 & $\mathrm{~F}$ & & 57 & N.C. & cancer of ovary & & - & - & \\
\hline 9 & F & & 65 & N.C. & cancer of liver & & - & - & \\
\hline 10 & $\mathbf{M}$ & & 34 & N.C. & trauma & & - & - & \\
\hline 11 & $\mathbf{M}$ & & 58 & N.C. & diverticulitis & & - & - & \\
\hline 12 & F & & 63 & N.C. & cirrhosis & & - & - & \\
\hline 13 & $\mathbf{M}$ & & 19 & N.C. & trauma & & - & - & \\
\hline
\end{tabular}

* $\mathrm{S}=$ Schizophrenia

**N.C. = Normal control

***N.B. = Normal brain 
et al., 1968). G.v.d. is also found in more than one disease with quantitative differences from normal (Tomlinson and Kitchener, 1972) (g.v.d. is rarely seen in Huntington's disease). Whether the cells are more closely analogous to the "aging" type of degeneration such as g.v.d., or to the "storage" type of defect such as neuronal ceroid lipofuscinosis is uncertain pending detailed biochemical and refined histochemical analysis of the cells. Toxicity (e.g. phenothiazine effect) or deficiency (e.g. vitamin E) with selective vulnerability of N.A.P. and septal cells are other possibly more likely explanations to be considered. Trans-synaptic degeneration producing this type of effect (lipid degeneration) is without precedent and therefore probably unlikely, although possible.

The functional effect of the lesions is a matter of speculation. Non-specificity of diseases with the change is a strong point for non-specificity of effect. On the other hand, the evidence must be considered at least suggestive that these patients with "functional psychosis" have some form of organic brain disease.

\section{ACKNOWLEDGEMENTS}

This work was supported by the Medical Research Council of Canada. The technical assistance of $F$. Eastwood, B. Potter, G. Gatward, M. Taylor, and R. Brown is greatfully acknowledged. Case material and controls were kindly provided by the Dept. of Pathology, New Addenbrooke's Hospital, Cambridge (Prof. A. Gresham, Dr. C. Treip) and Runwell Hospital, Wickford (Prof. J. Corsellis).

\section{REFERENCES}

AVERBACK, P. (1980a). Lesions of the nucleus ansae peduncularis in human neuro-psychiatric disease. (To appear in Archives of Neurology)

AVERBACK, P. (1980b) Ultrastructure of swollen N.A.P. cells in chronic neurological disease, in press.

HIRANO, A., DEMBITZER, H.M., KURLAND, L.T., ZIMMERMAN, H.M. (1968). The fine structure of some intraganglionic alterations. Journal of Neuropathology and Experimental Neurology 27, 167.

METTLER, F.A. (1948). Neuroanatomy, Mosby, St. Louis.

TOMLINSON, B.E., KITCHENER, D. (1972). Granulovacuolar degeneration of hippocampal pyramidal cells. Journal of Pathology $106,165$. 